Tamás Csiki

\title{
Stereotypes Surrounding the Hungarian Peasantry During the Years of the First World War
}

\begin{abstract}
The paper examines the use and political, ideological, and social meanings of the term peasant and its synonyms. It reflects on how these meanings were modified as a consequence of the structural and experiential changes in the social situation of the agrarian population. The textual analysis is based on publications from the press during the First World War and, thus, the concepts, in their contexts, can be understood first as instruments for propaganda and mental mobilization, that is to say, as political action. Second, these notions and concepts also incorporated past (historical) phenomena and future expectations, through which they offered arguments for programs and ideas to transform society. Third, the texts frequently prompted debates in the media, which strengthened the discursive nature of the press, the controlled publicity, and the usage of vocabulary and language. By the same token, they can also represent a chance to examine the social stereotypes and the experience of personal relations crystallized in these texts.
\end{abstract}

Keywords: peasant, stereotypes, press, social class, national character, World War I

During the course of the First World War, ${ }^{1}$ discovering the Hungarian peasantry became fashionable, and newspapers, books, and parliamentary speeches fought to outdo each other in praising their valuable characteristic features and patriotic merits. ${ }^{2}$ The anonymous author of Tolnavármegye és a Közérdek [Tolna County and Public Interest] was not the only one who reached this conclusion, and public attention was obviously due to the large

1 This study has been completed in the program of MTA-DE Ethnology Research Group [MTA-DE Néprajzi Kutatócsoport]. The article was translated by Pál Csontos.

2 Tolnavármegye és a Közérdek 1916: 2.

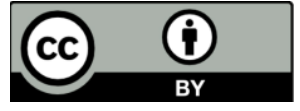


number of agricultural laborers serving on the battlefields. ${ }^{3}$ For me, however, this presents an opportunity to examine these features as well as the use and political, ideological, and social meanings of the term peasant and its synonyms. It can be very educational to see how these meanings were modified as a consequence of the structural and experiential changes in the social situation of the agrarian population. (Following mass recruitment and conscription, peasants became soldiers and often victims). ${ }^{4}$ For sources, I have used publications from the contemporary press and, thus, the concepts, in their contexts, can be understood first as instruments for propaganda and mental mobilization, that is to say, as political action. Second, these notions and concepts also incorporated past (historical) phenomena and future expectations, through which they offered arguments for programs and ideas to transform society. Third, the texts frequently prompted debates in the media, which strengthened the discursive nature of the press, the controlled publicity, and the usage of vocabulary and language. By the same token, they can also represent a chance to examine the social stereotypes and the experience of personal relations crystallized in these texts.

\section{Images of peasantry before the war}

Before presenting the virtues and merits of peasant draftees and volunteers, it makes sense to refer back to the portrayal of peasants in the press before the world war. The January 31, 1914, lead article of the newspaper Közérdek [Public Interest] contains a range of essential elements of these depictions. The fundamental message was that the problems of villages and their naïve people require urgent remedies. "The people here exist in pristine savagery, like that of the meadows. Ethically, they gradually deteriorate; materially, they become powerless; physically, they degenerate; and mentally, they idly vegetate." 5 Furthermore, this portrayal continues, village conditions are, if anything, even worse than they were centuries ago. What has been lost, is the

3 In Hungary, in 1910, the peasant population headcount was 11.4 million, which was $62 \%$ of the total population figure. Out of this, more than 1 million were drafted. On peasant society, Gunst 1998: 125-175.

4 The total number of dead and MIA in the war was 381,000, roughly $70 \%$ of which were agricultural laborers. The agricultural policy of the European countries during the war, as well as the organization of village societies (connections between relatives and generations) and the changes in gender roles and labor relations were analyzed by Benjamin Ziemann. Ziemann 2014: 382-407.

5 A fatornyos falu 1914: 1. (The author of the article was anonymous) 
Stereotypes Surrounding the Hungarian Peasantry...

"patriotic zeal in the heart of the people. Every peasant today is a self-centered egotist, trembling for their own individual welfare, whose heart is interminably filled with the dangerous distrust towards their superiors as well as the doleful desperation about their own fate." 6

In these lines, the portrayal by the educated few, inherited from the time of the enlightenment, is repeated: the people (the village) means unculturedness, uncivilizedness, closeness to nature, and separation from urban (middle-class) culture. In the ideological context of nationalism, this is identical with the lack of patriotic fervor, uninterestedness in politics, and seclusion from the national community. This is exactly why finding a cure for the problems is necessary to strengthen the nation, which the author naturalistically demonstrates with the biological metaphor ever more popular for the right-wing radical ideology after the war. ("The fatal ulcers have to be cut out of the thatched roofs of the villages..., instead of the tired and sick blood, florid and healthy blood needs to be filtered into the arteries of the nation." ${ }^{7}$

The text above did not detail the specific methods of therapy. These were included in the editorial of Esztergom és Vidéke [Esztergom and Its Surroundings] published in January 1912. Its author was the editor of the paper, Farkas Kempelen, a nationally acclaimed writer, who himself specified the ideology upon which his interpretation of society was built. "You don't need to be a biased chauvinist", he states; it is sufficient to acquire experience about how

"the primitive morals of the people (and by people I mean the agrarian population) are in the best position, where genuinely Hungarian people live in a large majority in a given area, and they are less ideal in the case of mixed people who have evolved into being Hungarian."

This nationalism (as opposed to the one present in the previous text) is based on ethnicity. It identifies genuinely Hungarian people, who are less primitive, and people of foreign origin who have become Hungarian. However, it considers their systems of social relations similar, which also determines the method of elevating them to our level. Peasantry is related to the middle class the same way as a child is related to an adult.

A fatornyos falu 1914: 1.

A fatornyos falu 1914: 2 .

Kempelen 1912: 1.

9 Kempelen 1912: 1. (Emphasis in original.) In Esatergom, Kempelen named the Turks, the Serbs, the Slovaks and the Schwabians. 
"Peasants, or agricultural people, to use a more recent and honest moniker for them, have to be considered a child and need to be treated as a child. Educating them, leading them and approaching them with love would be the expected approach towards them from each and every member of the genteel order, who are called the middle class these days." 10

Apparently, Kempelen is wont to use precise terminology. At the same time, however, in a manner reminiscent of contemporary evolutionist ethnology and psychology, he discusses childish and primitive people as a collective of creatures of instinct, who do not have a personality. Their savage morals are also a consequence of this. ${ }^{11}$ Education and paternalistic guidance can lead to the elimination of their cultural backwardness and to the dissipation of their distrust towards the middle class.

\section{The military merits of peasants}

It was these unfavorable characteristic features and traits that Hungarian peasants carried with them to war, ${ }^{12}$ where they had a chance to change them. It is a widely accepted opinion among historiographers that the bellicose enthusiasm during the first few months of the war came chiefly from the middle class, whose members were the number one participants in the rites of communal identification with the cause of the war. ${ }^{13}$ In Budapest, in the fall of 1914, public events called Háborís elóadások [War Lectures] and Háborús délutánok [War Matinées] offered collective experiences in addition to routine propaganda and acquisition of information about the war from week to week, for which purpose the simple folks were also used. ${ }^{14}$ Ferenc Herczeg, a celebrated contemporary writer, gave a talk on November 28, 1914 in the grand hall of the Ritz hotel by the title $A$ körkatona [The Private Soldier], ${ }^{15}$ which was also published by Új Idók [New Times] and Magyar

10 Kempelen 1912: 1-2.

11 Contemporary ethnologists had a similar opinion about "primitive" peoples outside Europe.

12 Stereotypes about the peasantry were more varied than this. See Vári 2012: 245-270. On the ethnographic stereotypes about Germans in Hungary, see Csíki 2018: 45-55.

13 van den Linden-Mergner 1991: 9.

14 On the talks, see Turbucz 2016: 81-96; Balázs 2016: 143-165. Dániel Szabó analyzed popular theatrical plays from this perspective. Szabó 1999: 185-198.

15 Ferenc Herczeg (born: Franz Herzog, 1863-1954) came from a wealthy German middleclass family and learned Hungarian at the age of 12. During the war years, he was chairman of the institution called Military Aid Office. 
Figyelo" [Hungarian Monitor], both of which he was the editor, so members of the middle class could read it all over Hungary. ${ }^{16}$

The train of thought in these presentations spanned from the epic heroes of antiquity to the unknown rank-and-file private soldiers in the world war; from the individual to the faceless mass, and the "democratization" of heroism led to the revival of the nation.

"One of the most miraculous marvels of the war is the current behavior of the Hungarian folks. Militancy, momentum and patriotic willingness to make sacrifices have all been brought into the nation by the Hungarian peasants." 17

This meant that the private soldiers defending national culture were identical with the peasants, whose character also changed in the war. Opinions from abroad,

"based on old-fashioned and romantic images, were still trying to find the son of the wastelands in the Hungarian peasant who makes merry by crying and whose intellectual horizon is restricted to little brown girls, the fiddles of gypsy musicians, saddle horses, and wine from Tokaj. Recently, a different image of our agrarian folk has started to take shape in the awareness of the Budapest literati, which is at least as untrue as its predecessor. This image shows the Hungarian peasant to be a stubborn, shrewd, money-minded and, above all, sensual human animal." 18

Herczeg, who was considered to be an excellent orator, portrayed the Hungarian peasantry in literary representations (rhetorical images), while moving away from the romantic-folksy and modern-urban caricatures, which he replaced with elements of the equally romanticized valiant national character. $^{19}$ Thus, the historical national character could experience a revival through the heroism, gallantry, and gentility of Hungarian peasants, a revival, however, which did not include the possibility of social integration for them. ${ }^{20}$

16 The rest of the program was equally commendable. Opera singer Anna Medek performed popular folksy songs and the celebrated actress, Sári Fedák, sang wartime love ditties, which the audience received with "double affection". Herczeg 1914a: 12.

17 Herczeg 1914b: 12.

18 Herczeg 1914b: 409-413. (Herczeg alluded to the naturalist trend at the turn of the century, primarily to the portrayal of peasants by the writer Zsigmond Móricz.)

19 This was originally characteristic of the nobility.

20 At the same time, Herczeg was critical of the middle class, which he identified with intellectuals ("our intellectuals discussed nationalism and war glory as if these had been some outdated stage props"), and hoped that the war would result in the cleansing and strengthening of the so-called upper classes. Herczeg 1914b: 412-413. 
The talk by Ferenc Herczeg was published not only in Új Idók and Magyar Figyeló but also in Nagykórös és Vidéke [Nagykőrös and Its Surroundings], a periodical issued by the organization called Nagykốrösi Gazdasági Egyesïlet [The Economic Association of Nagykőrös]. It focused only on passages about the peasantry, to which editor Kázmér Magyar added a brief comment. He praised Herczeg's words but, nevertheless, disapproved of the implication that Hungarian agrarian laborers had to be discovered by the Budapest literati and that a world war was necessary for that recognition. ("We, the provinces, have tried to move in this direction so far in vain." ${ }^{21}$ In sum, the author of the article resented that the peasantry was but a tool for propaganda purposes, he stressed the lack of social attention, and expressed a claim for the right of the provinces, i.e., the public opinion in the small towns, to be equally present and active in the discourse on this topic.

An even more radical critique came from István Milotay, a young journalist working for the periodical Új Nemzedék [New Generation]. In his view, the discovery of the Hungarian peasant by the politicians, writers and journalists of the governing party, including Ferenc Herczeg, was nothing more than an act of hypocrisy. In fact, they had established a dogma of the political and moral disparagement of the peasantry. They treated it as "a malicious enemy and an unreasonable horde; they could never even mention it in contexts other than condemnation, derision and laughter."22 In Milotay's opinion, since 1867, and even before that date, the political elite had not been able or willing to do anything about attacks by a foreign power against national independence, ${ }^{23}$ the national middle class had crumbled, and consequently the country could not rely on anything else but "the depths of masses of Hungarian peasants." 24 In essence, the author used the peasantry as an implement in politics against the executive power and opined that the moral excellence of the former, which found expression in heroism, discipline, endurance, self-esteem, and ingenuity, would not only become an organic

21 Magyar 1915a: 1-2. Magyar (1858-1942) graduated from the Academy of Economics in Magyaróvár, and from 1894 on, he acted as the national supervisor for agricultural education and agrarian schools organized for the peasantry. He is also known as a collector in the field of ethnography. Cf. Magyar 1915b.

22 Milotay 1915: 1.

23 In 1867, the Austro-Hungarian Monarchy was established through a compromise between Austria and Hungary. By mentioning a foreign power, Milotay refers to the Austrian government. (In the last third of the $19^{\text {th }}$ century, Hungarian political parties were organized not along political ideologies and affiliations but along the lines of public-law relations with Austria.)

24 Milotay 1915: 1. 
part of the national character (just like in Herczeg), but would also enable it to embody a "commitment to sustain the nation and the state" 25 .

The ambitious rhetorical output of Herczeg and Milotay were soon to be superseded. Even the first sentence of a piece published by Barnabás Enyedi, a journalist with considerable belletristic ambitions, in the February 4, 1915 issue of Magyar Paizs [Hungarian Shield] was full of captivating force. "Above the softly whispering magnificent Carpathian Mountains, the ancient, eternal and proud Hungarian bird, called turul, still flies high as the symbol of the guardian soul of the Hungarian race." 26 The turul motif is present throughout the text, establishing a clear semantic field. The defenders of the homeland, the proud peasant folks of the Hungarian land, had brought their love of freedom with them from Asia and, as fierce and formidable as they are in fight and battle, they are as gentle and refined a culture-race after the struggle.

"This is the Hungarian people, noble in its intentions and chivalrous in its acts; the hardworking peasant of the Hungarian land, who dresses the wounds of his enemy that he himself has inflicted. No other people but the Hungarians carry this characteristic nobility in their hearts. Hungarian ladies and gentlemen: hats off to the Hungarian peasant." 27

This manner of address is based on conceptual dichotomies and identifications, the orienting factor for which is the peasant. What is stressed, as opposed to the bourgeois society, is the national society; social status is opposed to racial character. Meanwhile, the people and the nation, as well as the folk/racial character and national character, become identical and filled with the spiritual contents of valor (heroism, chivalry and humaneness). ${ }^{28}$ However, this is still not the final note of symbolic argumentation. The clandestine alliance of our opponents is getting weaker and weaker, while

"the sun of Hungarians is rising with a new light from the East. The Islamic world, which has risen to life from centuries of captive dreams, lends us its

25 Milotay 1915: 2. Milotay was from a landed gentry family and, in a number of other pieces written by him, he also emphasized that the national middle class, which he identified as the gentry, needed to be augmented from the ranks of the peasantry. Szabó 2003: 314.

26 Enyedy 1915: 1. The bird turul is the mythic animal of the Árpád lineage present in Hungarian origin myths, usually identified as an eagle. (Eagles are well-known Eurasian symbols.)

27 Enyedy 1915: 1.

28 The text is full of examples of the words race and soul in various forms and contexts (for example, "the fertile soil of Hungarian racial existence", "huge racial agony", "the living soul of the Hungarian people", "the soul of the Hungarian nation"). 
enormous powers in this war. Their freedom-fight reaches us from fertile Arabia, the watersheds of the rivers Tigris and Euphrates and the legendary Hungarian land of Lake Maeotis through the wilderness of the Caucasus Mountains and the Bosphorus Strait to the beloved stretches of our Hungarian Great Plain."29

The actual federal system of our country or the topos of the protective bastion of Christianity (the West), frequently occurring in other texts, are not important for the author. But, contrasted with this, Hungarians have been left alone in their struggle, to which strength and the belief in victory comes from the consciousness of origin, and from the identification with the East represented by mystical geographical landscapes.

The notion of the people appeared in the January 9, 1915, lead article of the newspaper Népszava [People's Voice] in a rather different conceptual context, at a different level of abstraction, and with a different political and social-organizational content, manifested even by the choice of the title ( $A$ polgárkatonák [The Civilian Soldiers]). ${ }^{30}$ It was written about peasants who were tilling the soil just yesterday, the workers, the craftsmen, the salesmen, and the officials, who all stood their ground not only among the rank and file, but also as officers, leading to the birth of the people's army in the fall of 1914.

The anonymous author of the article also discusses the merits of these soldiers without any particular degree of pathos. The civilian members of the population (referred to as civilians) became soldiers with an inbred obedience and endurance, which made them fit for defending the homeland. However, this also implied certain tasks to be taken care of by the government, including the passing into law of a whole range of social bills: on the prohibition of woman and child labor at night, as well as daytime restrictions; on creating healthy work environments; on the provision of substantial food and clothes for children; and even on the nationalization of public healthcare, including free access to medical treatments. In this argumentation, the notion of the people is expanded, incorporating workers, craftsmen, tradesmen, and office workers, in addition to peasants (referred to here as citizens). As the first part of compound words (in people's army, people's or folk education), it raises the possibility of a perspective for the democratization of society. As the military defense of the state is generally obligatory for everyone (even the social democrats supported Hungary's participation in the war), it required

29 Enyedy 1915: 1. Lake Maeotis is today's Azov Sea; a scene on the ancient migration route of the Hungarians.

30 Népszava was the daily newspaper of the Hungarian Social Democratic Party, founded in 1890. 
"the democratic organization" of the army, ${ }^{31}$ and it was primarily connected to claims for labor law reforms, mostly in the world of industrial work and for the expansion of social policies. ${ }^{32}$

The valiant conduct of Hungarian peasant soldiers was also noted by representatives of the allied forces. Miklós Lázár, a war correspondent for the newspaper Pesti Napló [Pest Diary], reported a conversation on the Galician Front in January, 1915 with a Prussian chief of staff major, who had direct experience with Hungarian troops. Based upon the works of Hungarian writers translated into German, Baron P. had previous knowledge only about Budapest, cheerful women, members of the gentry 33 and rich merchants. ("I thought there was nothing else in that country." 34 ) No wonder he was surprised to notice Hungarian peasants in the trenches.

"I have seen them storming enemy lines in shirt sleeves under barrage, then burying their fallen after the battle was over, and their faces were always the same: proud, sad, and delightfully virile. Even their relationship with their officers is different from that of the soldiers of any other nation. There is a childlike love glowing in their eyes towards their superiors, who, in turn, treat them in a patronizing fashion I have never experienced before. Through this regiment of soldiers, I have learned to love and respect Hungary." 35

It is possible that the Prussian major only used the patterns of obligatory politeness and perhaps his words were tailored by the reporter to fit the expectations of propaganda. Nevertheless, it is also possible, if not likely, that for him the patriarchal relationship between the officers and the peasant soldiers was the most striking feature that he had not experienced anywhere else before. ${ }^{36}$

A polgárkatonák 1915: 1. (Emphasis in original.)

A polgárkatonák 1915: 1.

33 In Hungary, following the English pattern, the term gentry was applied to members of the landed nobility.

34 Lázár 1915: 2.

35 Lázár 1915: 2.

36 General Boroevic, who was one of the military commanders of the Austro-Hungarian Monarchy of Croatian descent, also noted the military merits of peasants, which the newspapers cited for their readers in words of enthusiasm and pathos: "Hungarian farmers, the pearls of the nation, are excellent soldiers. They are valiant and persistent: almost insensitive to hardship and necessity, always cheerful, obedient and loyal, like a good child... May God keep them safe as the strongest pillars of Hungary." A magyar gazda a csatatéren 1915: 245-246. 


\section{Peasants in the hinterland}

The newspapers of the day did not fail to note the civilian merits and virtues of agricultural laborers either, which also provided a chance for demonstrating their social contacts. Secondary school teacher and editor László Kőrösy from Esæztergom wrote that our nation-sustaining peasantry, which became a new order after the 1848 emancipation of serfs, provided the middle class and the capital city with grain, which is why the primary expectation of the state was that it should take care of the peasantry's future needs (through modernizing agricultural activities, establishing agrarian schools and folk libraries or through adult education). Then, after eliminating backwardness as well as mental and cultural shoddiness, the peasants' "sober originality, independence, and clear common sense would already be a Hungarian national trait." 37 György Borbély, a grammar school teacher from Zalaegerszeg and founding editor of Magyar Paizs underlined that it had been this huge and strong mass that had sustained the country for a thousand years:

"we do not notice that, while we are walking on the sidewalk in our patent-leather shoes, they would be pulling the cart together with their oxen in mud up to their necks... and we get white bread and golden yellow cake on our table as a result." ${ }^{\text {"38 }}$

Nurturing is also symbolic here: "The deteriorating people of our sybaritic cities would become extinct in three generations if they did not continuosly refresh it by nurturing it annually through new children bursting out of their strong bosom." 39

The peasantry as a nurturing order was also a frequent topic in the periodical Gazdaszövetség [Farmers' Association], which followed the agrarian ideology. It is the love of the Hungarian land (the native soil), they wrote, that encourages our soldiers, who are strong in body and mind and are superior to the enemy in the matter of morals and discipline. This publication continued with the view that the people have been taught through agrarian and cooperative principles to fear god, to respect authority, and to practice solidarity, and that this is what can fill the nation with hope: the Hungarian

Kőrösy 1916: 1.

Borbély 1915: 1.

Borbély 1915: 1. 
fields yield enough bread so that neither the combatants, nor the people in the hinterland need to be afraid of starvation or famine. 40

This ideologically determined plastic manner of delineation, based on the opposition between rural and urban settlements, was further elaborated in articles written by a young chaplain, Endre Hamvas. ${ }^{41}$ He urged that genuinely Hungarian Christian people should attend the coronation ceremony of Charles IV ${ }^{42}$ which would confirm respect towards the king and faith from his subjects, while the monarch could learn about the virtues of the "thousand-year-old soul of the people" 43 (including its religiousness, noble morals, diligence and valor). Thus, Hamvas idealized the charismatic (medieval) relationship between Charles IV, the crowned father of the nation, and the people he protected. His approach was concomitant with a more heated confrontation between the various social groups than ever before, a division of Hungarians, and social exclusions. The author disapproved that, between the people and its king, there was a middle class and a new element of it. Although the new Hungarians will attend the coronation ceremony, they are not familiar with the ancient virtues and, for them, the past is alien, or even loathsome, and, "while they bear a Hungarian name, it is just an accommodation process, exactly like in the case of people from Galicia." 44

The topic of the peasantry was also discussed at the February, 1916 session of the upper house, when Prime Minister István Tisza contributed to the

40 Földmivelők a háborúban 1914: 1301; A haza védelme 1914: 1321; Nemzeti erőink forrásai 1914: 1637. After the war broke out, the organization called Hungarian Farmers' Association delivered a call to "Hungarian farmers" through the cooperatives and farmers' circles, in which the national vocation of agricultural laborers was specified. No religion, language, political party or profession can separate the sons of a nation from one another, "we are one and united in the defense of our homeland. Specifically, you, agricultural laborers, who create the history of a thousand years with your plows in times of peace, and who are bound to the domestic land with a thousand times more ties than anybody else, should demonstrate what Hungarian agricultural laborers can do when it comes to making a sacrifice for the motherland not only through perspiration but through shedding blood." Szózat a gazdákhoz 1914: 1. As regards those who stay at home, they should put aside every means of individual profiteering and self-interest and take care of the wounded, the orphans, and the returning soldiers in order to ensure that "every other occupation" is duly taken care of. Szózat a gazdákhoz 1914: 1.

41 The ecclesiastical career of Hamvas (1890-1970) was rather impressive later. In 1944, he was elected Bishop of Csanád, in 1961, the Chairman of the Hungarian Catholic Bishops' Conference and, in 1964, Archbishop of Kalocsa.

42 This was held after the death of Franz Josef, in December 1916.

43 Hamvas 1916: 5.

44 Hamvas 1916: 5. In these lines, a thinly veiled instance of anti-semitism is apparent: "new Hungarians" and "people from Galicia" functioned as references to members of the Jewry. 
debate. Thus, we can learn about his use of these concepts and the issues surrounding them. .5 He was worried about the birthrate and the decrease of the propagative power of the Hungarian people. As a result, and in order to reduce child mortality, he advocated the increase of the number of midwives and the supervision of their work, vaccination and immunization as well as the attention of the Hungarian educated people. Tisza's arguments were unusually personal in tone, and he also added his own sad comments. Landowners ceased to be landlords because they spent most of their time in cities, in southern retreats, or in the climatic resorts of the north. By this token he expressed his hope about how the war

"opened up the soul of the Hungarian people for many a sceptic, who have learned to appreciate Hungarian peasants... The upper layers of society should realize that the most sacred obligation for them is to act as, and fulfill the responsibilities of, a landlord at home, in their family nest or village." 46

Tisza, who preferred spending leisure time in his rural estate in the village of Geszt rather than the capital, ${ }^{47}$ used different terminology in different situations. This time, he spoke as a landowner of the upper house, and he idealized the orderly relationship surviving between landlords and the peasants who enjoyed the love and care of their lords because they needed education and personal examples. (This also played a part in the fact that, even during the war, Tisza refused to accept land reform and granting of suffrage to the majority of the peasantry.)

\section{A "conceptual-historical" debate about the term peasant}

On August 5, 1915, a national committee was formed to rebuild "the hearths destroyed in the war", which intended to organize the relief campaign in support of villages in the north of Hungary. 48 At the opening parliamentary session, attendees included MPs and members of the upper house, lord lieutenants, and deputy lieutenants, as well as mayors and other ecclesiastical and lay dignitaries. One of the addresses was delivered by Jenő

45 As newspapers carried parts of the speech, it did not remain unknown to the masses either. A földesúr 1916: 1-2.

46 Fórendiházi Napló IV. 1916: 203-204.

47 Vermes 1994: 185

48 At the end of 1914 and the beginning of 1915, the Russian army pillaged and burned several settlements in the northeastern part of Hungary, from which the population fled. 
Rákosi, ${ }^{49}$ who emphasized that that the outcome of this war would be decided by the peasants, "and specifically peasants who grow wheat and raise farm beasts and children. It is this triple love that the patriotism of the Hungarian peasant springs from and his uncontestable valor is rooted in." 50 Rákosi was perhaps not the best of orators, yet his speech, which was transcribed and published by the paper Budapesti Hirlap, ${ }^{51}$ and especially his use of the term peasant, prompted extremely vivid and mixed reactions, which illustrate the opinions of the paper's readers.

The first response came from Antal Ujlaki, a journalist and writer less known than Rákosi, who was the editor of the daily $S_{z e g e d i}$ Friss Újság [Fresh Newspaper of Szeged]. Ujlaki profoundly agreed with the content of the text; however, he had his reservations about the word peasant. In his opinion, there were no more peasants in the sense the term had been used back in the 1870s and 1880s, when "we could still see old peasants whose childhood started in the thirties or forties." 52 Whoever Rákosi considers a peasant, in the city of Szeged would be regarded as

"a citizen or, if he is poorer, he would be a manual worker. Poor men at court in the city of Debrecen would humiliate themselves saying 'I'm a peasant.' In contrast, agricultural laborers living next to the river Tisza are not peasants to the extent that they call each other sir, like 'Sir Biczók' or 'Sir Csamangó.' They are so sure about their gentlemanly status that they would regard it a serious affront if they were called peasants." ${ }^{53}$

Rákosi replied immediately, and he criticized the changes in the denominations of occupations and addresses.

"Today, there are no more servants but help or personnel, no masters but tradespeople, no menservants but apprentices. What's the use?... To me, the word peasant is not an indication of membership in a caste, nor a nickname but rather the collective term for small holders who independently cultivate the soil. To me, this word sounds nicer, more honest and Hungarian than the ones trying to take its place. ${ }^{34}$

49 Jenő Rákosi (1842-1929) was a well-known writer, theatrical director and newspaper editor. He was born into a family of German descent; his father was an under-steward and also had a small estate.

50 Feldúlt tűzhelyeinkért 1915: 1.

51 Elpusztult falvaink fölépítése 1915: 8; Feldúlt tűzhelyeinkért 1915: 1-2.

52 Ujlaki 1915: 10.

53 Ujlaki 1915: 10. (Emphasis in the original.)

54 Rákosi 1915: 10. 
That is to say, Rákosi here tries to protest against the assumption that he would use the term in a pejorative sense to "belittle our people" and hastens to add for emphasis that he is proud that his ancestors were "peasants tilling the soil" in Sopron County. ${ }^{55}$

Following the polemics between Rákosi and Ujlaki, the editorial office of Budapesti Hirlap received quite a number of letters from the readers. According to linguist Endre Horváth, author of Magyar helyesirás szótára és szabályai [Dictionary and Rules of Hungarian Orthography], it was the peasants that preserved the purity of the language and age-old Hungarian vocabulary. In contrast, city folks let their knack of language be ruined by their knowledge and command of German or French. Horváth further posited that it was also the peasants who preserved and cherished Hungarian customs, virtues and morals, including honesty, the love of land, sober frugality, and simplicity. Peasant folks were characterized by cleanliness, friendly hospitality, humility in fear of god, and self-conscious pride.

"This is the sense that Hungarians associate with the word peasant..., I reckon that our generation will be healthy, strong, and uncorrupted only until our good peasants are transformed by culture into modern people, a culture that will be killing an ancient strength of our people with each new generation." 56

A gentlewoman from the city of Sopron, Lászlóné Rábel, described who she considered to be a peasant in a much simpler and more plastic way:

"Well, the little barefooted peasant kids who happily splash their feet in rain puddles, are they perhaps middle-class kids or Hungarian-people kids? The little peasant boy and peasant girl who herd their gooselings on a green turf, are they perhaps agricultural laborer kids? No, not at all. They will surely remain peasant kids for ever." ${ }^{\prime 57}$

Reformed minister István Kájel from Felsöireg wrote about how the term was used in the village he lived in. It is not used in the farmers' circles, in the body of representatives or at settlement assemblies. If necessary, it is replaced with the word relatives or people, which would be used by and borrowed from either himself or the local Catholic priest. At best, it can be used at court or when talking to members of the nobility "out of modesty, to indicate how

55 Rákosi 1915: 10.

56 Horváth 1915: 10-11.

57 Rábel 1915: 10-11. (Emphasis in the original.) 
insignificant they are: I am a peasant." 58 However, he said if he were to address them like this at their table or after an assembly session, that is to say, in personal face-to-face communication, as he has done for testing, they would resent it. The minister then revealed that people were also interested in the actual meaning of the word peasant and that he would enlighten them in such cases as follows:

"I use this word for identifying a type of people. They don't get this moniker because of their uneducated status but for reasons of ancestry. Neither 'gypsy' nor 'Jewish,' but 'peasant,' which means that their father and mother were both agricultural laborers. I am also proud to say that my grandfather was a peasant, too, when he tilled the soil up around the locations pillaged." 59

An old reader of the paper commented on Kájel's letter, and suggested that it would be worth clarifying the etymology of peasant, which clearly expressed their system of values and attitude: it comes from the Old Slavic word "prost" and it means a person who has remained the same as when they were born.

"Simple and without any learning, coarse compared to their natural inclinations: in one word, only at a slightly higher degree than an animal. This stratum of people had no title or rank during the era of feudalism. They had no distinction such as those of barons, counts or other members of nobility." 60

The growing discussion in the paper prompted Zoltan Hanvay, the oldfashioned landowner of the settlement Hanva, ${ }^{61}$ to send a letter to the daily Az Ujjág [The Newspaper]. ${ }^{62}$ In his opinion, the term peasant is by no means a derogatory nickname but "an ancient material of the nation, which cultivates the motherland." 63 True, he says, these people have innate defects such as living from day to day, a lack of forward-looking frugality, and the fluctuation of the folk spirit, by which he meant enthusiasm for no apparent reason

58 Kájel 1915: 12

59 Kájel 1915: 12.

60 A ,paraszt” 1915: 11.

61 Gömör and Kishont Counties.

62 Hanvay (1840-1922) graduated from the academy of law in Sárospatak, following which he managed his landed property estate. He wrote literary pieces and studies on hunting and dog breeding. (He signed his article as "The Hermit of Hanva".)

63 Falusi levél a főszerkesztőhöz 1915: 36. 
followed by desperation caused by the slightest inconvenience. ${ }^{64}$ Naturally, they also have ancient virtues, which are handed down from one generation to the next: "The wonderful love of the homeland, a never-say-die patriotism and willingness to sacrifice." 65 All this makes the writer of the letter happy and content, filling him with a landowner's pride, saying, "I am proud of my peasants." $66 \mathrm{He}$ then calls his fellow landowners to get involved in caring for their subjects: "Love the Hungarian peasants, raise and guide them in the right direction?' 67

\section{Summary and conclusion}

I have cited only a few text sources above but it is certainly sufficient to prove that during the course of World War I, the notion of the peasant became the center of attention in public and political perceptions. The authors of these articles of varying lengths were writers, teachers, and editors, but also novice chaplains and retired ministry officials, who all had different levels of education but who each aspired to shape public opinion via a press controlled by censorship.

These authors used a range of cultural and genre patterns (notional schemes) in the course of presenting the military virtues of the peasantry. These primarily included three components: 1) portrayals of national characterology, which became popular in the $19^{\text {th }}$ century and reflected the influence of German anthroposophy (the virtues formerly typical of the nobility, including valor, chivalry, self-esteem and pride, that were then associated with the peasantry); 2) scholarly and journalistic debates and discussions on the origins and the ancient history of Hungarians (in which, by the turn of the $19^{\text {th }}$ and $20^{\text {th }}$ centuries, the influential concept was related to eastern

64 There is also an example mentioned here: according to rumors, women wailed all over the village: "This is the end for us; the German emperor is already marching his soldiers against us into the Carpathians.” Falusi levél a föszerkesztőhöz 1915: 36.

65 Falusi levél a főszerkesztőhöz 1915: 36. Hanvay kept an exact account on how 120 individuals fought on the front out of a village population of 860 .

66 Falusi levél a főszerkesztőhöz 1915: 37.

67 Falusi levél a fôszerkesztőhöz 1915: 37. (Emphasis in original.) In another piece of his, Hanvay wrote about the situative and relational use of the notion. Dignitaries from the city and the county wish to meet the people only before the election of members of the parliament. "And even then, how? Well, by becoming friendly with them in the course of drinking and telling them about general and equal suffrage. Following the elections though, if they run into them on a dam, they shout at them: 'Get out of the way, you stinking peasant!'” Hanvay 1917: 17-18. 
Stereotypes Surrounding the Hungarian Peasantry...

origins);68 and 3) literary representations of the folk spirit expressed in folk culture and traditions, propagated by Herder. (In several cases, the texts used literary representations of the peasantry both for and against their arguments.) As part and parcel of historical discourse, all of the above was complemented by external threats, anti-Western feelings, and the mobilizing force of the struggle of abandoned Hungarians for survival. Thus, the ideas that these authors relied on (such as nationalism or political romanticism) can be easily delineated. However, in their cases, we can not only observe the vulgarization of these ideas or a mechanic adoption of the images that had become topoi, but also a re-creation of them with a different level of erudition and rhetoric. As a consequence, the texts could contribute to the strengthening of the national image constructed on the analogy of Gemeinschaft during the course of the world war, as well as to the transformation thereof into propaganda, of which the peasantry, the formerly subjected people, could also become an organic part. ${ }^{69}$ (The term people used with a democratic meaning, as the community of citizens constituting the state, could be found only in the press of the Social Democrats.)

The writers of the articles and letters must have been familiar with the organic concepts of society, popular in agrarian neo-conservative ideology in Hungary and all over Europe. In the hinterland, peasants fulfilled the task of being a medieval kind of nurturing order (providing not only food but also human resources for the other orders), ${ }^{70}$ which often implied political and (ethno)cultural conflicts of interest (i.e., instances of seclusion). Ferenc Herczeg criticized the middle class, while István Milotay passed judgments on the political elite, but folk culture, as the protection of the ancient and autochtonous Hungarian culture was also suitable for the expression of thinly veiled anti-modernity, as well as anti-semitism, and opposition to the capital city.

The term peasant is also at the center of public attention and, although Jenő Rákosi had considerable intellectual authority, his usage of this word was contested by many, which may lead us to conclusions related to social history. It seems that the notion behind the term and its interpretation could also incorporate the everyday experiences of social structures in villages, together with the actions and the personal relations inherent in the manner of address, as well as the dynamics of permanence, change, and future possi-

68 Szűcs 1985: 1985: 35-37.

69 Research of the German national character also became more intensive during the war than it was before. Cf. Lackó 1988: 149.

70 In fact, however, the urban population had to face increasing levels of food shortage as of 1916, which made the urban-rural opposition even more intense. 
bilities.71 Lászlóné Rábel from Sopron and Zoltán Hanvay identified the peasant with its constant patriarchal lifestyle, regulated by ancient customs, while István Kájel underlined the importance of descent, in opposition to which the term "middle-class) citizen signified social emancipation (not necessarily in political programs but in way of life or lifestyle). At the same time, the use and meanings of the term were also differentiated through the roles of the agents related to social situations and everyday communication situations. Ultimately, however, the oftentimes emotional and vehement series of polemics augmented by the world war were also about crossing or consolidating the mental borderlines between master(s) and peasant(s), as well as about the re-confirmation of individual and group identities.

\section{Bibliography}

A fatornyos falu

1914 Közérdek. January 31.

A földesúr

1916 Néptanitók Lapja. March 9. 1-2.

A baza védelme

1914 Gazdaszövetség. August 22. 1321.

A magyar gazda a csatatéren

1915 Harangszó. June 13. 245-246.

A ,paraszt"

1915 Budapesti Hirlap. August 31. 11.

A polgárkatonák

1915 Népszava. January 9. 1.

BALÁZS, Eszter

2016 A magyar társadalom önmozgósítása az első világháború elején: a budapesti háborús előadássorozatok és a „háború kultúrái” In Iván Bertényi Ifj. - László Boka - Anikó Katona (ed.): Propaganda, politika, bétkëzznapi és magas kultúra, múvészet és média a Nagy Háborúban. 143-165. Budapest: Országos Széchényi Könyvtár

BORBÉLY, György

1915 A parasztság. Magyar Paizs. October 28. 1.

CSÍKI, Tamás

2018 Ethnische und gesellschaftliche Stereotype in den ethnografischen Beschreibungen der Ungarndeutschen um die Wende vom 19. zum 20. Jahrhundert. Ungarn Jabrbuch. Zeitschrift für interdisziplinäre Hungarologie. 34. 45-55.

71 Koselleck 1979: 107-130. 
Stereotypes Surrounding the Hungarian Peasantry...

Elpusztult falvaink fölépitése

1915 Budapesti Hirlap. August 6. 8.

ENYEDY, Barnabás

1915 A nemzet jobb sorsa most fordul. Magyar Paizs. February 4. 1.

Falusi levél a föszerkesztôhör

1915 Az Újság. November 7. 36-37.

Felduilt tüzhelyeinkért

1915 Budapesti Hirlap. August 8. 1-2.

Földmivelök a háborúban

1914 Gazdaszövetség. August 15. 1301.

Förendiházi Napló IV.

1916 February 25. 203-204.

GUNST, Péter

1998 Hungarian Agrarian Society from the emancipation to the end of World War I. In Péter, Gunst (ed.): Hungarian Agrarian Society from the emancipation of serfs (1848) to the reprivatization of land (1998). 125-175. New York: Eastern European Monographs

HAMVAS, Endre

1916 A koronázás és a nép. Eştergom. December 24. 5.

HANVAY, Zoltán

1917 Egy ág rezeda felejthetetlen jó öreg királyunk koporsójára. Rimaszombat: Rábely

HERCZEG, Ferenc

1914a Háborús délutánok. Budapesti Hirlap. November 29. 12.

1914b A közkatona. Magyar Figyelő IV. 409-413.

HORVÁTH, Endre

1915 A magyar „paraszt”. Budapesti Hirlap. August 17. 10-11.

KÁJEL, István

1915 A magyar „paraszt”. Budapesti Hirlap. August 28. 12.

KEMPELEN, Farkas

1912 Az esztergomi nép neveléséről. I-II. Esztergom és Vidéke. January 11. 1-2. KOSELLECK, Reinhart

1979 Vergangene Zukunft. Zur Semantik geschichtlicher Zeiten. Frankfurt: Suhrkamp KŐRÖSY, László

1916 Parasztságunk jövőjéről. Esz̨tergom és Vidéke. March 16. 1.

LACKÓ, Miklós

1988 Korszellem és tudomány. Budapest: Gondolat

LÁZÁR, Miklós

1915 Magyar paraszt a háborúban. Pesti Napló. January 25. 2.

van der LINDEN, Marcel - MERGNER, Gottfried

1991 Kriegsbegeisterung und mentale Kriegsvorbereitung. In Marcel van der Linden - Gottfried Mergner (ed.): Kriegsbegeisterung und mentale Kriegsvorbereitung. 8-22. Berlin: Duncker \& Humblot

MAGYAR, Kázmér

1915a A közkatona. Nagykörös és Vidéke. January 26. 1-2. 
1915b A magyar parasæt. Apróságok felöle. Nagykőrös: Nagykőrösi Gazdasági Egyesület

MILOTAY, István

1915 Urak és parasztok. Új Nemzedék. March 7. 1-3.

Nemzeti eröink forrásai

1914 Gazdaszövetség. December 12. 1637.

RÁBEL, Lászlóné

1915 A magyar „paraszt”. Budapesti Hirlap. August 17. 10-11.

RÁKOSI, Jenő

1915 A magyar „paraszt”. Budapesti Hirlap. August 11. 10.

SZABÓ, Dániel

1999 Magyarország nem volt, hanem lesz. Háborús lelkesedés a populáris színielőadá sok tükrében. In Gábor Gyáni - Gábor Pajkossy (ed.): $A$ pesti polgár. Tanulmányok Vörös Károly emlékére. 185-198. Debrecen: Csokonai kiadó

SZABÓ, Miklós

2003 Az újkonzervativizmus és a jobboldali radikalizmus története (1867-1918). Budapest: Új Mandátum

Szózat a gazdákhoz

1914 Pápai Lapok. August 30. 1.

SZÜCS, Jenő

1985 Történeti „eredet”-kérdések és nemzeti tudat. Valóság. 3. 31-49.

Tolnavármegye és a Közérdek.

1916 May 29.2.

TURBUCZ, Péter

2016 Háborús előadások szervezése Magyarországon 1914-ben - történeti vázlat. Jelkép. 1. 81-96.

UJLAKI, Antal

1915 A magyar „paraszt”. Budapesti Hirlap. August 11. 10.

VÁRI, András

2012 Sieben Bilder des ungarischen Bauern 1790-1919. In Daniela Münkel -Frank Uekötter (ed.): Das Bild des Bauern: Selbst- und Fremdwahrnehmungen vom Mittelalter bis ins 21. Jahrbundert. 245-270. Göttingen: Vandenhoeck \& Ruprecht

VERMES, Gábor

1994 Tisza István. Budapest: Századvég

ZIEMANN, Benjamin

2014 Agrarian Society. In Jay Winter (ed.): The Cambridge History of the First World War. Vol. 2. 382-407. Cambridge: Cambridge University Press 